\title{
The Effect of Unripe Carica Papaya Seeds Extract on Serum Profiles of Some Liver Functional Enzymes in Wistar Rat \\ EB Ezenwanne, O Abuda
}

\begin{abstract}
Background: There are several reports of various medicinal applications and healthcare benefits of the mature unripe carica papaya fruit seeds. It was the aim of this study to assess possible alterations in the serum levels of some key liver functional enzymes and related compounds in doses of aqueous extract of carica papaya seeds in wistar rats.

Methods: Healthy rats of comparable weight and age, were organized into four groups. One other group served as control. The Test animals received daily oral dose of 50,100, 200 and $400 \mathrm{mg} / \mathrm{kg}$ of body weight of the extract, respectively, for 21 days through orogastric tube. The control group received no treatments with the seeds extract.

Results: Analysis of blood samples at the end of treatments revealed significant decrease $\quad(p \leq 0.05)$ in serum alanine aminotransferase (ALT), aspartate aminotransferase (AST) and alkaline phosphatase (ALP) enzymes. Conjugated bilirubin showed significant increase $(\mathrm{p} \leq 0.05)$ in animals receiving the $200 \mathrm{mg} / \mathrm{kg}$ dose of the extract. Total serum proteins value showed no definite alterations.

Conclusion: The observed fall in serum aminotransferase enzymes (ALP, ALT, AST) coupled with the rise in serum conjugated bilirubin levels seen in this study, was clear demonstration of possible hepatomodulatory activities of carica papaya seeds with hepatoprotective effects.
\end{abstract}

Keywords: Carica papaya seeds, hepatomodulatory properties, wistar Rat

From: Department of Physiology, School of Basic Medical Sciences, College of Medical Sciences, University of Benin, Benin City, Nigeria.

Correspondence: Dr E Ezenwanne, Department of Physiology, School of Basic Medical Sciences College of Medical Sciences, University of Benin, Benin City, Nigeria.

E-mail: ezenwanneeeb@yahoo.co.uk 


\section{INTRODUCTION}

Carica papaya, commonly known as pawpaw in local parlance in most communities of West Africa, was first cultivated in Mexico and now widely distributed in many tropical countries including Asia and South America. The plant can be monoecious, dioecious or hermaphroditic with male and female parts. Presently, the part of the plant that is of greater interest to researchers is the seeds.

Phytochemical analysis of the seeds revealed that it contains bactericidal aglycone glucotropeaolin benzyl isothiocyanate, glocoside, sinigrin, and carpasemine. Fermentation distillations of carica papaya seeds also identified 106 volatile compounds of $4 \%$ alcohol, $91.8 \%$ ethanol, $4.8 \%$ methanol, $2.2 \% \mathrm{~N}$-propanol and $1.2 \%$ unknown non-alcohol compound. The ripe fruit of carica papaya is used in the culinary of salads as in Thai cuisines (1). The seed is widely used in Nigeria in indigenous food condiments and as added ingredient in the processing of drinks, jams and cadies. Presently, there are several reports of the medicinal efficacy of the matured unripe carica papaya fruit seeds, and most of the claims are related to indigenous healthcare herbal formulations and practices. Thus, carica papaya seed is employed in a range of medicinal healthcare uses amongst indigenous populations in Nigeria, other parts of Africa, Asia and South Americas. For example, recent unconfirmed reports noted that carica papaya seeds extract were effective in the treatment of sore teeth, ringworms and have been the prescription for the removal of cancerous growth in Cuba; serve as anti-sickling agent for the reversal of sickling properties (2); used in treatment of hypertension and diabetes mellitus (3); employed as contraceptive agent in the male $(4,5,1,6)$; employed for its antibacterial properties in inhibiting the growth of gram positive and gram negative organisms (7). 


\section{Ezenwanne et al}

Since many indigenous communities still depend on herbal medicinal formulations for healthcare needs, the fact remains that very little knowledge is available concerning the mechanism of action of the constituents of these plants employed in indigenous medicinal formulations, including possible toxicity (8). It was the aim of this study to evaluate possible alterations in the serum levels of some key liver functional enzymes and related compounds following doses of aqueous extract of matured unripe carica papaya seeds in wistar rats.

\section{MATERIALS AND METHOD}

Matured unripe carica papaya fruits were obtained from private farms in Benin City, Edo State, Nigeria. The seeds were prepared by sun drying. The dried seeds were pulverized into fine powdered form. The preparation was soaked in distilled water for extraction of the constituents. The solution was filtered to separate the residue, and the solvent was placed in the evaporator at about $60^{\circ} \mathrm{C}$. The extraction procedure yielded the paste weighing about $38 \mathrm{~g}$. The extract was kept in clean sample containers and stored in refrigerator for preservation. The various doses $(\mathrm{mg} / \mathrm{kg})$ of the extract were determined by the method earlier described by previous workers (9).

Twenty adult wistar rats of comparable age and weight were kept to acclimatize in the animal house for a period of one week. Baseline values which included, the serum levels of liver enzymes alanine aminotransferase (ALT), aspartate aminotransferase (AST) and alkaline phosphatase (ALP) were determined. The serum levels of conjugated and unconjugated bilirubins, including the total plasma proteins level were also determined. Mean body weights of each group were recorded before and after the experiments. The animals were fed with livestock feeds and clean water throughout the experiments. 
The rats were organized into four groups of four animals per group. One other group served as control. In a group, each animal received one of the doses of the extract for the period of 21 days, thus: Group A (Control), received no treatment with the extract throughout the experiments. Group B, received 50mg/kg, Group C received 100mg/kg, Group D received 200mg/kg and Group E received 400mg/kg, respectively.

The extract was administered through orogastric tube. At the end of the administrations, blood samples were collected from the abdominal aorta using hypodermic syringes and micropipettes. The samples were stored in lithium-heparin bottles and thereafter, analysed for the aforementioned parameters using automated spectrophotometric analyzer.

\section{Statistical analysis}

Data from various animal groups were pooled and subjected to statistical analysis employing Students' $T$ test, and values of $\mathrm{p} \leq 0.05$ were regarded as statistically significant.

\section{RESULTS}

A decrease in serum alkaline phosphatase enzyme $(\mathrm{p} \leq 0.05)$ was observed in rats of groups $\mathrm{D}$ and $\mathrm{E}$ that received the 200 and $400 \mathrm{mg} / \mathrm{kg}$ doses of the extract, respectively (Table 2). Similarly there was a decrease $(\mathrm{p} \leq 0.05)$ in serum alanine aminotransferase enzyme in animals of groups $\mathrm{D}$ and $\mathrm{E}($ Table 2$)$. A decrease $(\mathrm{p} \leq 0.05)$ in the serum aspartate aminotransferase level was also observed in animals of group D that received the $200 \mathrm{mg} / \mathrm{kg}$ dose of the extract (Table 2). Serum conjugated bilirubin showed significant increase $(p \leq 0.05)$ in animals of group $D$ treated with the $200 \mathrm{mg} / \mathrm{kg}$ dose, and there was an observable (but not statistically significant) increase in animals of group E, receiving the $400 \mathrm{mg} / \mathrm{kg}$ dose of the extract (Table 3). Mean body weight in each 
group of rats was not appreciably altered at the end of the experiments (table 1). Serum unconjugated bilirubin and total plasma proteins level did not show appreciable alteration throughout the experiments (Table 3).

\section{DISCUSSION}

The analysis of the results of this study revealed definite alterations in serum levels of three hepatic enzymes at the end of the administrations with the papaya seeds extract. Serum conjugated bilirubin level also featured notable alteration (Tables 2 and 3).

There was a decrease $(\mathrm{p} \leq 0.05)$ in the serum levels of alkaline phosphatase (ALP), alanine aminotransferase (ALT) and aspartate aminotransferase (AST) in animals of group D that received the $200 \mathrm{mg} / \mathrm{kg}$ dose of the extract, and this featured in corresponding decrease in the serum levels of the enzymes ALP and ALT in animals of group E, receiving the $400 \mathrm{mg} / \mathrm{kg}$ dose (Table 2).

Studies to evaluate damage to liver tissues have shown that serum concentration of hepatic enzymes alanine aminotransferase, aspartate aminotransferrase and alkaline phosphatise, are important indicators of the functional integrity of the liver cells (10). According to earlier workers, hepatocellular enzyme markers are non-functional with negligible systemic concentration in normal situations, but leak into general circulation in necrosis or damage to hepatic cells (11). Thus, the enzymes commonly employed as test indicators in the assessment determination of hepatocellular damages are the aminotransferases (ALT, AST, ALP). For example, a rise in plasma aminotransferase activity is a sensitive indicator of damage to hepatic cells. Thus, the observed decreases in serum aminotransferase enzymes level in this study is 
noted as consistent with the notion of possible hepatoprotective properties of carica papaya seeds earlier proposed by some workers (12). It is also suggestive from present data that constituents of carica papaya seeds may have hepatomodulatory properties on some metabolic functions of the liver. Thus, the results of this study clearly indicate that carica papaya seeds may have properties with some biologically-active principle that accounts for the observed decrease in the serum aminotransferase enzymes. It is noteworthy that earlier phytochemical analysis of carica papaya seeds showed that it contains a natural toxin reported to have potent diverse biological activities (13).

A number of independent studies examined the proposed hepatoprotective mode of action of some medicinal plants believed to be mediated through combinations with antioxidant and free radicals scavenging activities $(12,14)$. It was observed that among the notable problems of liver function are those related to deficiencies in bilirubin metabolism, a function evaluated through assessment steps based on decreased hepatocytes uptake of bilirubin, impaired conjugation and decreased hepatocytes secretion of bilirubin (15). Other research findings have also shown that serum bilirubin value is often associated with condition of haemolysis or billiary obstruction (14). It was noted that elevated values in serum conjugated bilirubin (similar to the observation in animals of group D in this study, including the observable but not statistically significant increase in animals of group E), is reliable indication that the liver cells are conjugating bilirubin normally. However, it is noteworthy that elevated values in serum conjugated bilirubin may not be from hepato-biliary source. Nevertheless, the fact remains that, serum aminotransferase enzymes value, serum conjugated and unconjugated bilirubins and total plasma proteins values, are important parameters in the assessment determination of functional integrity or diseases of the liver cells. The observations on serum profiles of these 
aforementioned functional parameters of the liver in this study strongly support the proposed hepatomodulatory properties and the notion of possible hepatoprotective effects of carica papaya seeds, and this is a likely tenable hypothesis for future research.

\section{CONCLUSION}

The serum profile of aminotransferase enzymes seen in this study lend credence to the claims of healthcare benefits of carica papaya seeds as contained in the indigenous herbal medicinal formulations. Since healthcare delivery in many parts of Africa, Asia, China, South America etc, appears to be shifting rapidly from emphasis to synthetic drugs to the use of herbal formulations, there is urgent need for research to ascertain clearer insight into the phytochemical properties of carica papaya seeds and gain knowledge of the mechanism of action of the active ingredients in the seed of this plant species. 


\section{REFERENCES}

1. Lohiya NK, Manivanna B, Mishra PK, Pathak N, Sriram S, Bande SS, and Panneerdoss S. Chloroform extract of Carica papaya seeds induced long-term reversible azoopermia in Langur monkey. Asian J of Andrology. 2002; 4: 17-26.

2. Thomas KD and Ajani B. Antisickling agent in an extract of unripe pawpaw fruit (Carica papaya). Royal Soc of Tropical Med and Hygiene. 1987; $\underline{81: 510-511}$

3. Gill LS. Carica papaya, In: Ethnomedicinal uses of plants in Nigeria, Benin City. UNIBEN Press. 1992; pp. 57-58.

4. Lohiya NK, Mishra PK, Pathak N, Manivannan B, Bhande SS, Panneerdoss S, and Sriram S. Efficacy trial on the purified compounds of the seeds of carica papaya for male contraception in Albino Rat. Reprod Toxicol 2005; 20: 135-148.

5. Udoh $\mathrm{P}$ and Kehinde A. Studies on the gonads of male albino rats. Phytotherapy Res. 1999; 13: 226-228.

6. Lohiya NK, Manivannan B and Garg PK. Toxicological investigation on the Methanol subfraction of the seed of carica papaya as male contraception in albino rats. Reproductive Toxicol. 2006; 22:461- 468.

7. Dawkins G, Hewitt H, Wint Y, Obiefuna PC, and Wint B. Antibacterial Effects of Carica papaya fruit on common wound organisms. West Indian Med J, 2003; 52(4):290- 292.

8. Mensah J, Okoli R, Turay A, and Ogie-Odia E. Phytochemical analysis of Medicinal plants used for hypertension in Edo State, Nigeria. Ethnobotanical Leaflets, 2009; $13: 1273-87$. 
9. Adeneye AA and Benebo AS. Protective effect of aqueous leaf and seed extract of phyllantus amarus on gentamicin and acetaminophen-induced nephrotoxic rats. J. Eth. Pharm., 2008; 118 (2):318-323.

10. Ozo G, Okoro I, Obi A and Nwoha P. Hepatoprotective role of Garcinia kola (Heckel) nut extract on ethamphetamine Induced neurotoxicity in mice. African J. Bioch Res, 2010; 4(3): 81-87.

11. Murray RK, Granner DK, Mayer PA and Rodwell VN. Harper's Biochemistry. $25^{\text {th }}$ Ed. McGraw Hill. New York. 2000; pp 242-245.

12. Lanhers MC, Joyeux M Soulimani R, Fleurentin J, Sayag M, Mortier F, Younos C, and Pelt, J. Hepatoprotective and anti-inflammatory effects of a traditional medicinal plant of Chile, Pneumus boldus. Planta Med. 1991; 57: 110-115.

13. Nakamura Y, Yoshimoto M, Murata Y, Shimoishi Y, Asai Y, Perk EY, and Sato K. Papaya seed represents a rich source of biologically active Isothiocyanate J Agric Food Chem 2007; 55: 4407-13.

14. Adeneye AA, Olagunju JA, Elias SO, Olatunbosun DO, Mustafa AO, Adeshile OI, Protective activities of the aqueous root extract of Harungana madagascariensis in acute and repeated acetaminophen hepatotoxic rats. Int $\mathbf{J}$ of Appld Res in Natural Products. 2008; 3: 29-42.

15. Crook M. Clinical chemistry and Metabolic Medicine. Edward Arnold Publishers, $7^{\text {th }}$ Ed. 2006; pp 250-28. 
Table 1: Mean body weight in various groups of rat at the end of experiments.

\begin{tabular}{lc}
\hline GROUP & MEAN WEIGHT $(\mathbf{g m})$ \\
\hline A (Control) & $201 \pm 2.10$ \\
B $(50 \mathrm{mg} / \mathrm{kg})$ & $197 \pm 4.30$ \\
C $(100 \mathrm{mg} / \mathrm{kg})$ & $199 \pm 3.20$ \\
D $(200 \mathrm{mg} / \mathrm{kg})$ & $192 \pm 2.90$ \\
E $(400 \mathrm{mg} / \mathrm{kg})$ & $200 \pm 1.40$
\end{tabular}

Values are Mean \pm SEM compared to the baseline control $(n=4)$

Table 2: Mean serum enzymes ALT, AST and ALP level (iu/l) in various groups of rat at the end of the administration of the various doses of carica papaya seeds extract.

\begin{tabular}{lccc}
\hline GROUP & ALP & ALT & AST \\
\hline A (Control) & $101.6 \pm 2.4$ & $89.5 \pm 2.0$ & $72.8 \pm 4.0$ \\
B & $98.4 \pm 1.3$ & $90.6 \pm 4.1$ & $71.4 \pm 2.0$ \\
C & $99.8 \pm 4.1$ & $86.4 \pm 2.0$ & $68.2 \pm 6.0$ \\
D & $59.2 \pm 2.1^{*}$ & $51.2 \pm 3.0^{*}$ & $51.1 \pm 1.0^{*}$ \\
E & $55.5 \pm 1.6^{*}$ & $56.0 \pm 2.2^{*}$ & $62.2 \pm 1.0$
\end{tabular}

*Significant values $(\mathrm{p} \leq 0.05)$ are Mean \pm SEM compared to baseline control, $(\mathrm{n}=4)$. 
Table 3: Mean total plasma proteins (mg/dL), serum Conjugated and Unconjugated bilirubins $(\mathrm{mg} / \mathrm{dL})$ in various groups of rat at the end of the experiments with various doses of carica papaya seeds extract.

\begin{tabular}{lccc}
\hline GROUP & $\begin{array}{c}\text { TOTAL } \\
\text { PROTEINS }\end{array}$ & $\begin{array}{c}\text { UNCONJUGATED } \\
\text { BILIRUBIN }\end{array}$ & $\begin{array}{c}\text { CONJUGATED } \\
\text { BILIRUBIN }\end{array}$ \\
\hline A (Control) & $5.3 \pm 0.4$ & $4.2 \pm 0.4$ & $0.5 \pm 0.1$ \\
B & $6.0 \pm 0.0$ & $5.6 \pm 4.2$ & $0.6 \pm 0.0$ \\
C & $5.0 \pm 2.0$ & $4.8 \pm 1.6$ & $0.4 \pm 1.0$ \\
D & $5.6 \pm 1.5$ & $4.5 \pm 0.7$ & $1.8 \pm 5.0^{*}$ \\
E & $5.2 \pm 2.0$ & $5.0 \pm 2.2$ & $1.0 \pm 1.0$ \\
\hline
\end{tabular}

*Significant value $(\mathrm{p} \leq 0.05)$ is the Mean \pm SEM compared to baseline control $(n=4)$. 